\title{
セルロース繊維の酸化漂白と污染性・洗浄性:
}

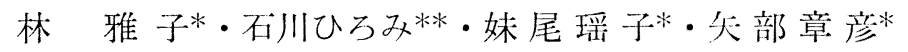 \\ *杂茶の水女子大学 (東京都文京区大塚)

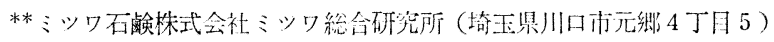

\section{Effect of Bleaching Degree to Soiling and Desoiling Properties of Cotton Fabrics}

\author{
Masako Hayashi*, Hiromi Ishikawa**, Yōko Senō* and Akihiko Yabe* \\ * Ochanomizu University (Otsuka, Bunkyo-ku, Tokyo) \\ ** Mitsuwa Soap Co., Ltd., Mitsuwa Central Laboratory (No. 5. Motogo 4-chome, Kawaguchi, Saitama)
}

Cotton fabrics for the standard artificial soiling recommended by JOCS are used for the treatment under conventional industrial conditions. Their properties, however, are different markedly from lot to lot owing to the finishing conditions. Accordingly, authors investigated the quality change of the fabrics during oxidative bleaching by sodium hypochlolite solution. The change of copper number and average polymerization degree (fluidity), as well as the tensile and tear strength of bleached fabrics were determined.

Results obtained are as follows:

1) With the increases in copper number and/or fluidity of oxidized cellulose, the fabrics become to be easily soiled and the artificially soiled fabrics are easily desoiled as well.

2) Copper number and fluidity of oxidized cellulose are intimately related to the tear and tensile strength. Chemical damage of the fabrics caused by bleaching can also be detected from these measurements.

The authors found a clue to control the bleaching condition in order to supply standard cotton fabrics of constant properties.

\section{1 緒 言}

纎維物質の各種の污れに対する污染性・洗浄性は, 各 々の纎維の物理的, 化学的特性に依存するのみでなく, 糸, 織物, 編物などの形になると, それぞれの構造的な 特性, さらには仕上げ加工による物理的, 化学的改質に よっても大幅に支配される。

われわれの経験でも, 洗浄力試験に使用される標淮木 綿人工污染布作成用の綿白布の污染性・洗浄性は, 毛羽 焼き,のり抜き, 精練, 漂白, 幅出し, 仕上げといら一 連の工程を, 特注で工業的に一定の処理をしているにも かかわらず, 仕上げ時期が異なると, その污染性・洗浄 性が大幅に異なり,しばしば問題になっている。

そこで本研究では, 污染性・洗浄性が暴なり, 問題と なっている 45 年度に仕上げ加工された原白布 (以下 S-45 原白布と略記）と，46 年度に仕上げ加工された原 白布 (S-46 原白布) について, それらの污染性・洗浄 性の差が何に起因しているのかを調べるため, 仕上げ工
程中, 特に問題と思われる漂白の段階に着目した。そし て, 次亜塩素酸ナトリウムの酸化漂白によるセルロース の変質につき, 主として, 銅価, 重合度変化などから調 べこれと污染性・洗浄性との関係を検討した ${ }^{1) \sim 5) 。 ~}$

\section{2 実験}

\section{$2 \cdot 1$ 銅価測定}

S-45 原白布と S-46 原白布の 2 種につき, 銅価測定 を行った。これは, JIS-P 8101-1961 の方法に従い, 七 ルロースの酸化の程度をカルボニル基の定量から求める ものである。それぞれ繰り返し 3 回ずつ行い，その平均 值を用いた。

$2 \cdot 2$ 次亜塩素酸ナトリゥムによる S-46 原白布の漂白

Table-1 に示すように, S-45 原白布と S-46 原白布 は, 銅価にして約 10 倍の差があり，S-45 原白布 0.502 に対し，S-46 原白布では 0.046 である。そこで, S-46 原白布を S-45 原白布と同程度の酸化状態にするための 漂白条件の決定を, 以下の方法で行った。 
Table-1 Comparison of properties between S-45 and S-46 cotton fabrics.

\begin{tabular}{c|c|c|c|c|c|c}
\hline Fabric & $\begin{array}{l}\text { Cloth } \\
\text { thikness } \\
(\times 0.01 \mathrm{~mm})\end{array}$ & $\begin{array}{c}\text { Density } \\
\text { Warp } \\
\text { Weft }\end{array}$ & $\begin{array}{c}\text { Who./cm }) \\
(\text { Reflectance }) \\
(\%)\end{array}$ & $\begin{array}{c}\text { Soiling } \\
\text { property } \\
(\text { Reflectance } \\
(\%)\end{array}$ & $\begin{array}{c}\text { Desoiling } \\
\text { property } \\
(\%)\end{array}$ & $\begin{array}{c}\text { Copper } \\
\text { number }\end{array}$ \\
\hline $\begin{array}{c}\text { S-45 } \\
\text { Cotton }\end{array}$ & 23.2 & $\begin{array}{l}24.5 \\
\text { fabrics }\end{array}$ & 77.6 & 19.0 & 29.8 & 0.502 \\
\hline $\begin{array}{c}\text { S-46 } \\
\text { Cotton } \\
\text { fabrics }\end{array}$ & 18.2 & $\begin{array}{l}25.0 \\
25.3\end{array}$ & 77.0 & 19.7 & 50.2 & 0.046 \\
\hline
\end{tabular}

試 薬 : 次画塩素酸ナトリウム

（茑薬アンチホルミン，有效塩素 $10 \%$ 以上）

濃 度 : $1,4 \%(1 \%$ 溶液中の有効塩素量 $980 \mathrm{ppm})$

温度 : $40,50,70^{\circ} \mathrm{C}$

浴 比 $: 1: 50$

時 間: $30,60,120,240 \mathrm{~min}$

かくはん：手かくはん，機械かくはん（ターゴトメー ター)

緩衝液：pH 10 (0.05 M-炭酸ナトリウム $: 0.1 M$-炭 酸水素ナトリウム $=3: 2$

\section{$2 \cdot 3$ 漂白布の污染性・洗浄性}

S-45 嗦白布，S-46 原白有および S-46 原白布を， それぞれの条件で漂白して得られた布について，活染性

・洗浄性を以下の方法で調べた。

\section{$2 \cdot 3 \cdot 1$ 污染性試験}

污染布の調製は連続污染機を使用し, 日本油化学協 会法に従った。污染した布は $5 \times 10 \mathrm{~cm}$ の大きさに切 断し， 2 枚折りにして表裏 2 力所を平沼反射率計で測 定, その平均值を布の污染性の目安とした。

\section{$2 \cdot 3 \cdot 2$ 洗浄性試験}

$2 \cdot 3 \cdot 1$ の活染布を以下の条件で洗浄した。

洗剤組成：アルキルベンゼンスルホン酸ナトリウム

\section{(LAS)}

$25 \%$

トリポリリン酸ナトリウム $25 \%$ 無水硫酸ナトリウム $50 \%$

$$
\begin{array}{ll}
\text { 濃 } & \text { 度 : } 0.2 \% \\
\text { 温 } & \text { 度 : } 40^{\circ} \mathrm{C} \\
\text { 浴 } & \text { 比 : } 1: 50 \\
\text { 時 } & \text { 間: } 15 \mathrm{~min}
\end{array}
$$$$
\text { かくはん：ターゴトメーター (100 rpm) }
$$

すすぎ：純水 $500 \mathrm{~m} l$ で 2 回

自然乾燥後, 洗浄布の表面反射率を測定し, 常法に より, 洗浄効率を次式から求めた。

$$
\begin{aligned}
& R_{W}: \text { 污染布洗浄後の反射率 } \\
& R_{S}: \text { 污染布反射率 } \\
& R_{O}: \text { 漂白布反射率 }
\end{aligned}
$$

\section{4 平均重合度測定}

JIS-L 1013-1963 の方法に従い，酸化銅アンモニア 溶液による粘度を王研式粘土計を使用して測定し, 平 均重合度を算出した。繰り返し 3 回行い, その平均值 を平均重合度とした。

\section{5 引張り強度・引き裂き強 度の測定}

$2 \cdot 5 \cdot 1$ 引張り強度

定速伸長型試験機(テンシロン) を使用し, 布のタテ方间の強度を 求めた。おのおの 10 枚以上の測 定を行い，その平均值を引張り強

度とした。

\section{$2 \cdot 5 \cdot 2$ 引き裂き強度}

エレメンドルフ式織物引き裂き試験機を用いて，布の タテ方向の強度を測定した。おのおの 10 枚以上の測定 を行い，その平均值を引き裂き強度とした。

\section{3 結 果}

\section{1 漂白条件による銅価の変化}

$2 \cdot 2$ に示すような条件で漂白を行うと, Fig.-1, 2 に 示すような結果が得られた。漂白条件がか酷となるに従 い, 銅洒は増大し, ほぼ直線的な関係がみられる。Fig. -2では，一連の実験に使用する布の総量や，漂白時の かくはん力の影響も考虑して，手かくはんで漂白した場 合の温度 $70^{\circ} \mathrm{C}$ での結果を示す。Fig. -2 より, $70^{\circ} \mathrm{C}$, 4\%, $120 \mathrm{~min}$ において, もっとも S-45 原白布に近い

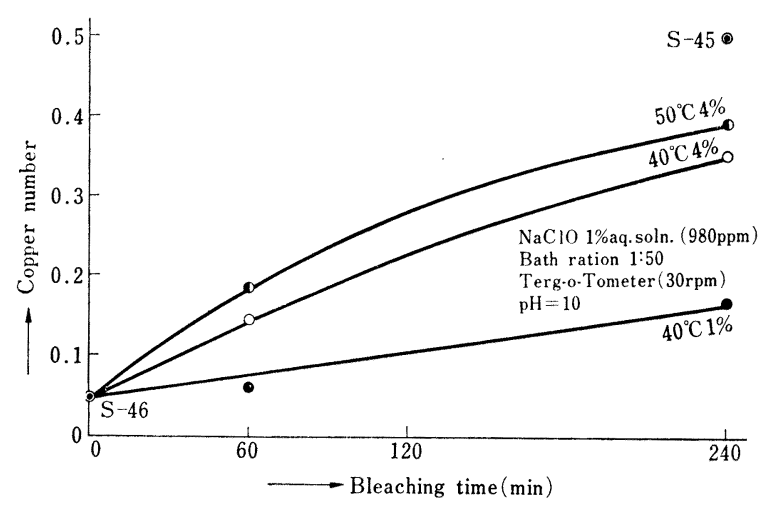

Fig.-1 Time change of copper number by various bleaching conditions.

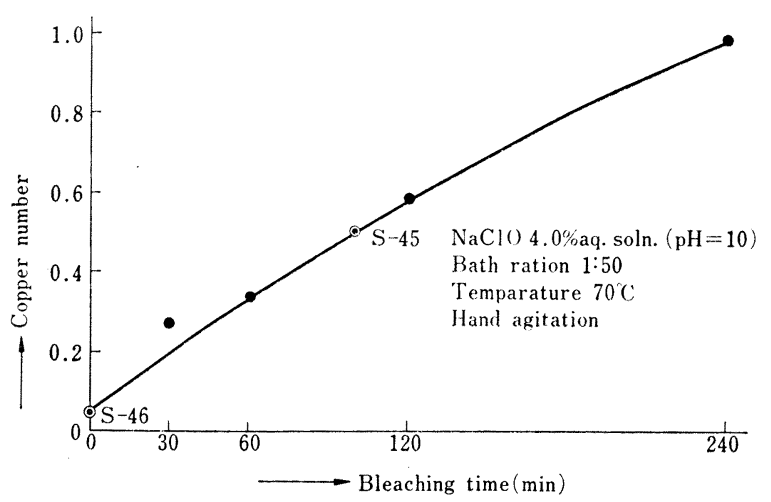

Fig.-2 Time change of copper number by bleaching. 
酸化状態が得られるこ上が明らか上公のた。

\section{2 漂白布の污染性・湤浄性}

话䛉り 条件 $\left.\left(70^{\circ} \mathrm{C}, 4 \%, 30\right), 60,120,240 \mathrm{~min}\right)$ で

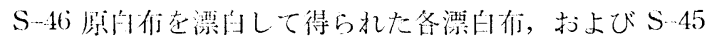

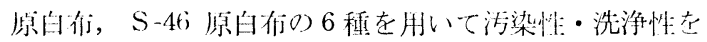

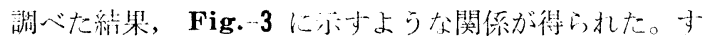

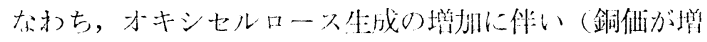
加するにつれて)，洼染されやすく，洗浮されやすい倾

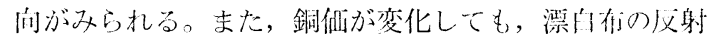
率にはほとんど差はみられない。

\section{$3 \cdot 3$ 平均重合度と銅価および污染性・洗浄性}

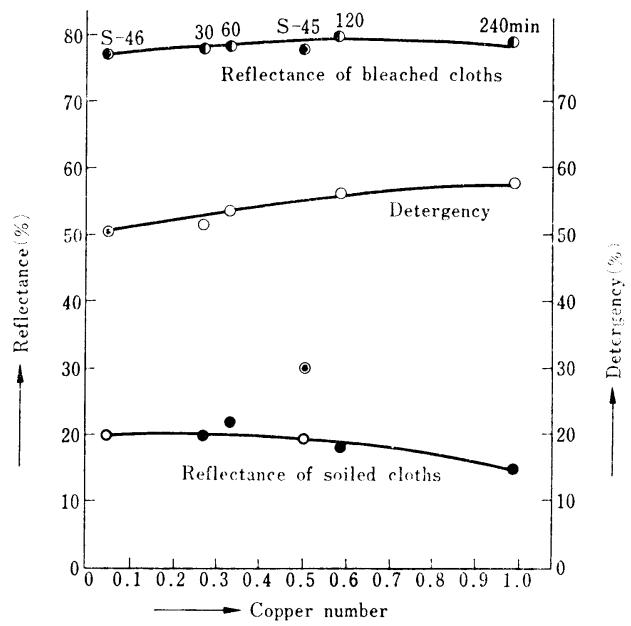

Fig.-3 Relation between copper number, reflectance, soiling and desoiling properties of bleached cotton. (Soiled by continuous soiling machine)

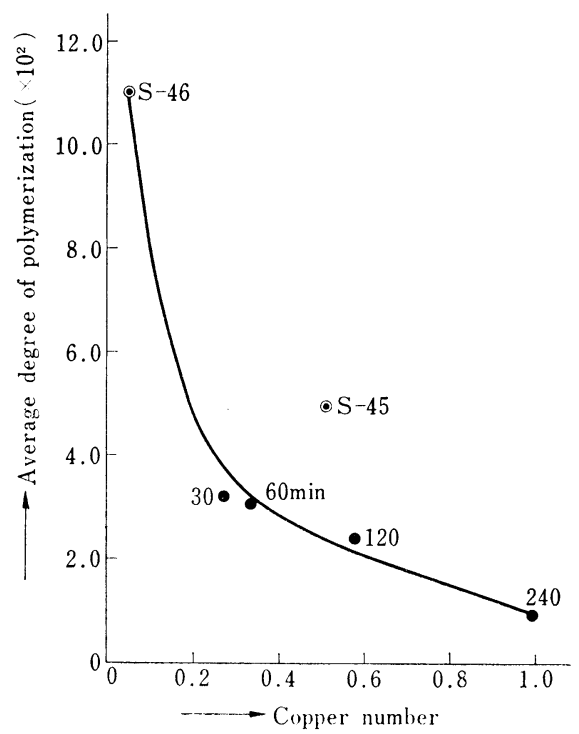

Fig.-4 Relation between average degree of polimerization and copper number of bleached cotton.

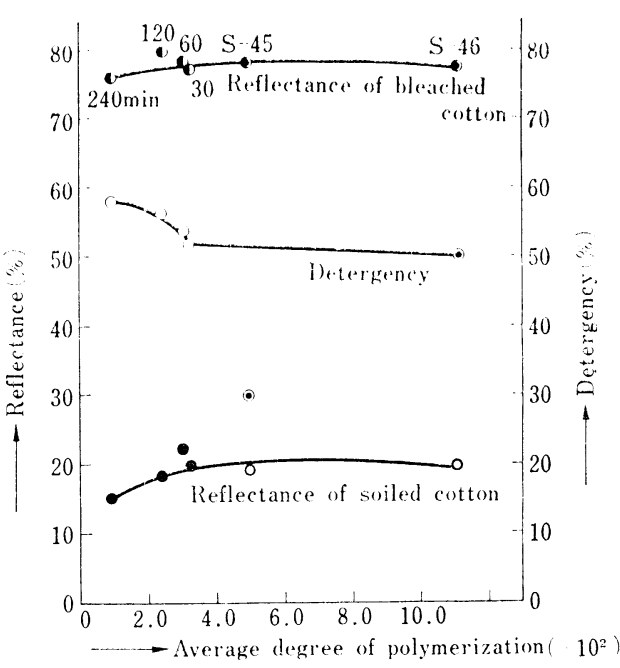

Fig.-5 Relation between average degree of polymerization vs. reflectance, soiling and desoiling properties of bleached cotton.

平均重合度と銅価の䦎には，Fig.-4に示寸上ら尔関 倸がみられ，オキシセルロ一久生成の增玑に伴い，平均 重合度低低下する。

平均重合度と活染性・・洗浄性の関保は Fig.-5に示さ れる上うに，平均重合废彽下に伴い，活染されやす く，洗浄されや寸くなる倾向がみられる。また，平均重 全度が変化しても，漂白布の反射彎の間には差はみられ 尔い。

以上より，セルロースのぜい化と污染性・洗浄性との 関倸については, 銅俇抢よび平均重合度が重要な目安で あることが明らかとなった。

3.4 銅徱および平均重合度 と引張り強度・引き裂き 強度の関係

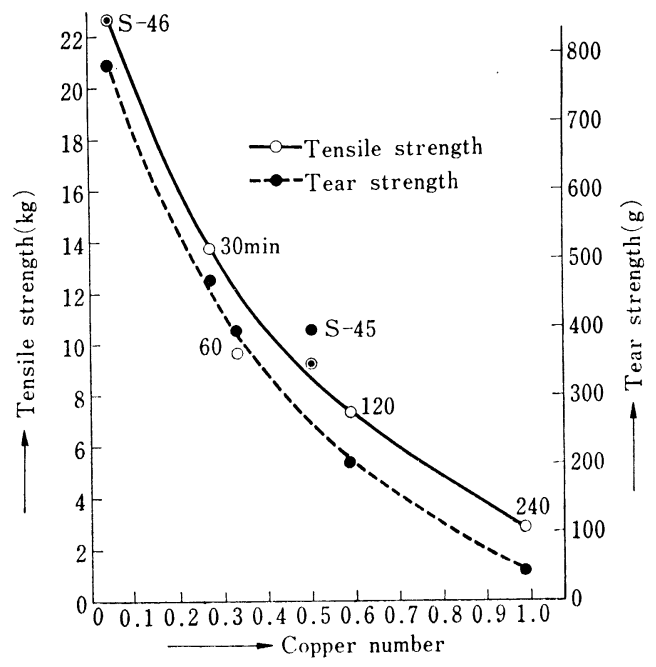

Fig.-6 Relation between copper number $\boldsymbol{v}$ s. tear and tensile strength. 
前項において銅価および平均重合度の測定から，漂白 布の化学的損傷が明らかになったが，ここで，当然受け ていると思われる機械的損傷についても検討した。

銅価と引張り強度・引き裂き強度との関係では，Fig.

-6に示すように, オキシセルロース生成の増加に従い, 引張り強度・引引き裂き強度共に著しく低下することが明 らかになった。

平均重合度と引張り強度・引き裂き強度の関係では,

Fig.7に示すように，斗均重合度の低下に伴い，引張 り強度・引き裂き強度共に顕著な低下がみられる。

\section{5 電子顕微鏡による観察}

以上の結果から，原白布と漂白布の間には，化学的に はかなりの差が認められたが，念のため, 䋊維表面の物 理的状態の観察を, 電子顕微鏡写真 $(\times 3000)$ により調 ベたが，はっきりした差はみられなかった。

\section{4 考察ならびに総括}

セルロースのぜい化と污染性・洗浄性との関係を, 主: として銅価および平均重合度について調べた以上の結果 につき，いくらかの考察を加える。

\section{1 銅価と白度（漂白布表面反射率）}

オキシセルロース生成の增加と自度とは無関係で亦 る。これは逆にいえば，漂白有の白度からセルロースの ぜい化壱知ることはできない。

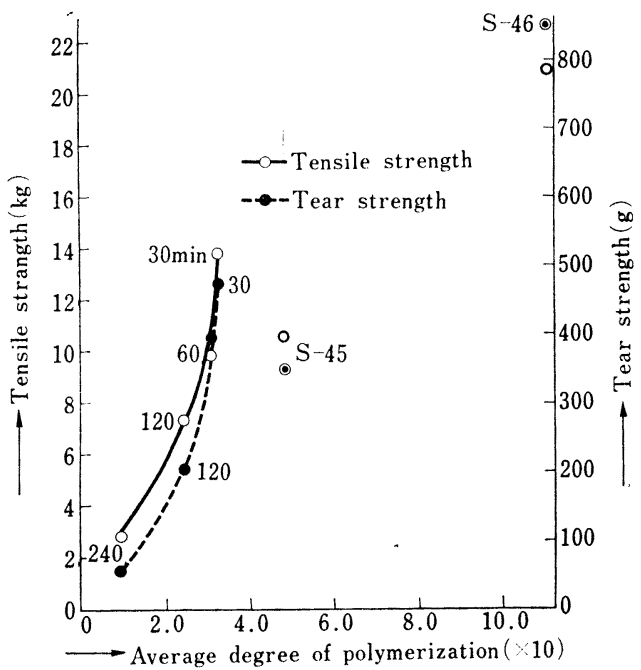

Fig.-7 Relation between average degree of polymerization and tensile and tear strength.
オキシセルロース生成の増加に伴い, 污染されやす く, 洗浄されやすい傾向がある。

\section{$4 \cdot 2$ 平均重合度との関係}

漂白による平均重合度の低下と，白度とは無関係であ る。

平均重合度の低下に伴い, 污染されやすく, 洗浄され やすい傾向がある。

セルロースのぜい化と污染性・洗浄性を調べる場合， 銅価および平均重合度の測定が重要な目安になり，この 両者間には，ほぼ逆比例の関係がみられる。実際の実験 にあたっては，より測定容易な銅価をまず調べるのが， 得策であると思われる。

\section{$4 \cdot 3$ 銅価および平均重合度と引張り強度・引き裂き} 強度との関係

オキシセルロース生成の増加に伴い, 引張り強度・引 き裂き強度は低下する。

また, 平均重合度の低下に従い, 引張り強度・引き裂 き強度が低下するのは当然であるが，酸化による繊維の 劣化は, むしろこれら物理試験によって, いっそう鋭敏 にとらえることができる。

銅価および平均重合度と, 引張り強度・引き裂き強度 との関係は深い。漂白による布の損傷はこれらのいずれ からも知ることができる。

次悪塩素酸ナトリウムを用いて, セルロースのぜい化 と污染性・洗浄性との関係を調べた本研究では, 漂白条 件により，オキシセルロース生成の著しいこと，および これを反映して平均重合度も大幅に変化すること,さら にこれが污染性・洗浄性に影響していることを明らかに することができた。

污染布用標準原白布の仕上げ加工の依頼にあたって は，これらの成果をもとにして，具体的な加工条件を示 すことが今後必要と思われるので, 引き続き検討を進め ている。

(昭和 48 年 11 月 28 日受理)

$$
\text { 文献 }
$$

1) Naber, Turner, J. Soc. Dyers \& Colourists., 61, 258 (1945)

2) Naber, Mhatre, Curr. Sci., 13, 256 (1944)

3) V.A. Shenai, O.P. Singh, J. Soc. Dyers \& Colourists., 87, 227 (1971)

4) V.A. Shenai, R.B. Prasad, Text. Res. J., 42, 603 (1972)

5) K. Dickinson, D. Heathcoth, J. Soc. Dyers \& Colourists., 88, 137 (1972) 